\title{
A STUDY OF THE NASCENT POLYPEPTIDES SYNTHESIZED ON THE FREE POLYRIBOSOMES OF RAT BRAIN IN VIVO'
}

\author{
O. Z. Sellinger, W. G. Ohlsson, \\ A. J. Frankel, J. M. Azcurra ${ }^{2}$ and Patricia D. Petiet \\ Mental Health Research Institute, University of Michigan Medical Center, Ann Arbor, \\ Michigan 48104
}

(Received 6 May 1970. Accepted 4 November 1970)

\begin{abstract}
The free polyribosomes of the cerebral cortex of the immature rat (12-14 days old) were exposed to very low concentrations of trypsin at $0^{\circ} \mathrm{C}$ and for very brief periods of time and the conditions under which their breakdown to smaller aggregates occurs were determined. Trypsin also caused the release of nascent, radioactive polypeptides from polyribosomes prelabelled with $\left[{ }^{14} \mathrm{C}\right]$ amino acids in vivo. An examination of the kinetics of release of the nascent chains by trypsin revealed that it was dependent on the concentration of trypsin as well as on the duration of incubation in the presence of trypsin. The influence of the nature of the $\left[{ }^{14} \mathrm{C}\right] \mathrm{amino}$ acid used as precursor of the nascent polypeptides and of the duration of the radioactive pulse in vivo was also determined. The radioactivity associated with polyribosomes as a result of the brief radioactive pulses administered ( 2 to 10 minutes) was incompletely removed even after the ribosomes were dissociated into subunits by EDTA. These findings suggest that the assembly of the cerebral ribosome in vivo must be a very rapid process, particularly in the immature animal.

The nature of the nascent, radioactive polypeptides was studied by disc gel and high voltage electrophoresis and by thin-layer and column chromatography. Evidence was obtained that a rather limited number of qualitatively different molecules resides on the polyribosomes at any given moment.
\end{abstract}

THERE is general agreement that ribosomes of neural tissue exist in the cell as aggregates (polyribosomes) held together by a strand of messenger RNA (TosCHI, 1959; DAtTA, 1966; Murthy, 1966; Zomzely, Roberts, Brown and Provost, 1966; JaCOB, Samec, Stevenin, Garel and Mandel, 1967. Campagnoni and Mahler, 1967; ZOMZELY, RoBerTS, GrUBER and Brown, 1968). As in other tissues, some of the polyribosomes of brain exist free in the cytoplasm and not attached to the membranes of the endoplasmic reticulum (Nievel and Cumings, 1967; Azcurra and Sellinger, 1967; Sellinger, Azcurra and Ohlsson, 1968; Merits, Cain, Rdzok and Minard, 1969). In an effort to extend some of our previous preliminary observations on brain ribosomes (AzCURRA and SELLINGER, 1967) and on differences in protein synthesis between the free and the endoplasmic reticulum-bound ribosomes (SELLINGER and OHLSson, 1969), we examined the synthesis of nascent polypeptides as it occurs on the free polyribosomes of the cerebral cortex of the immature rat after very brief ( 2 to 10 minutes) pulses in vivo of radioactive precursor amino acids. We also describe

\footnotetext{
${ }^{1}$ This research was supported by the United States Public Health Service Grant NB-06294.

${ }^{2}$ Present address. Instituto de Anatomia General y Embriologia, Facultad de Medicina, Universidad de Buenos Aires, Buenos Aires, Argentina.

Abbreviations used: TPCK $^{+}$L-(tosylamido-2-phenyl) ethyl chloromethyl ketone; LBI, lima bean inhibitor: PPO, 2,5 diphenyloxazole; dimethyl POPOP, 1,4 bis [2-(4-methyl-5-phenyloxazolyl]benzene; MTK medium, $\mathrm{Mg}$-acetate, tris- $\mathrm{HCl}$ and $\mathrm{KCl}$ medium (as specified under Methods); TS, trypsin supernatant; TP, trypsin pellet; DOC, deoxycholate.
} 
experiments involving controlled proteolysis of the polypeptides growing on the free polyribosomes in an effort to gain information on the structural association of the nascent chains and the ribosome. The results form this report.

\section{EXPERIMENTAL PROCEDURES}

Materials. TPCK ${ }^{+}$trypsin (subsequently abbreviated as trypsin), trypsin-LBI and chymotrypsin (twice recrystallized) were purchased from Worthington Biochemicals (Freehold, N.J.); sucrose (enzyme grade) and bovine serum albumin were products of Mann Research Laboratories (New York City); propylene oxide was obtained from Matheson, Coleman \& Bell (East Rutherford, N.J.); PPO and dimethyl POPOP were from Packard Instrument Co. (Downers Grove, Ill.); L- [U- $\left.{ }^{14} \mathrm{C}\right]$ leucine $(250 \mathrm{mCi} / \mathrm{mmol}), \mathrm{L}-\left[\mathrm{U}-{ }^{14} \mathrm{C}\right]$ phenylalanine $(375 \mathrm{mCi} / \mathrm{mol})$, and $\mathrm{L}-\left[\mathrm{U}-{ }^{14} \mathrm{C}\right] \mathrm{arginine}(250 \mathrm{mCi} /$ mmol) were from International Chemical \& Nuclear Co. (City of Industry, Calif.) and the Millipore filters (GA-6, 0.45 $\mu \mathrm{m}$ pore size) were from Gelman Instrument Co. (Ann Arbor, Mich.). Silica gel $\mathrm{G}$ was obtained from Brinkman Insttuments, Inc. (Westbury, N.Y.), and glutaraldehyde and Epon 812 were from Ladd Research Industries (Burlington, Vt.).

Animals. Male, Sprague-Dawley rats, 12-14 days old, were used throughout this study. While under light ether anaesthesia, they were injected intrathecally with no more than $0.05 \mathrm{ml}(6.5 \mu \mathrm{Ci})$ of a solution of the $\left[{ }^{14} \mathrm{C}\right]$ amino acid.

Isolation of the free polyribosomes. The animals were killed by decapitation and the brain was rapidly excised and placed on a petri dish resting on crushed ice. The cerebral cortex was dissected free of white matter as far as possible and after weighing, it was homogenized at $4^{\circ} \mathrm{C}$ by six manual up-and-down strokes of a Teflon-stainless pestle. Homogenates $(15-20 \%, \mathrm{w} / \mathrm{v})$ were prepared in a buffer containing: $5 \mathrm{~mm}-\mathrm{Mg}$-acetate, $20 \mathrm{mM}$-tris- $\mathrm{HCl}(\mathrm{pH} 7 \cdot 2$ ), and $25 \mathrm{mM}-\mathrm{KCl}$ (MTK medium). The homogenates were centrifuged at $20,000 \mathrm{~g}$ for $15 \mathrm{~min}$ and the supernatant fluid $(4 \mathrm{ml})$ was layered over $3.5 \mathrm{ml}$ of $0.5 \mathrm{M}$-sucrose resting on $4 \mathrm{ml}$ of $2.0 \mathrm{M}$-sucrose. Both sucrose solutions also contained MTK medium in which the concentration of $\mathrm{Mg}^{2}+$ was $10 \mathrm{mM}$. Centrifugation was at $4^{\circ} \mathrm{C}$ for $120 \mathrm{~min}$ at $269,000 \mathrm{~g}$ in the Spinco Ty-65 rotor. The resulting pellet consisted of free polyribosomes of a high degree of purity (Fig. 1, below).

Suspensions of the free polyribosomes in $20 \mathrm{~mm}$-tris $(\mathrm{pH} 7 \cdot 2)$ containing $25 \mathrm{mM}-\mathrm{KCl}$ were mixed with one-tenth of their volume of $3 \%(\mathrm{w} / \mathrm{v}) \mathrm{Na}$-deoxycholate $(\mathrm{pH}$ 7-0) and were centrifuged at 204,000 $g$ for $50 \mathrm{~min}$. The ribosomal pellets were suspended in distilled water for analysis (Table 1 below). The main purpose of these experiments was to assess the degree of contamination of the free polyribosomes with lipid (MURTY and HaLlinan, 1969). The deoxycholate soluble fraction was not investigated. Samples of free polyribosomes $(0.8 \mathrm{ml}$ containing about $0.2 \mathrm{mg}$ of protein) in MTK medium $\left(1 \mathrm{mM}-\mathrm{Mg}^{2+}\right)$ were layered on a linear gradient $(4.8 \mathrm{ml})$ of sucrose $(15-40 \%$, w/v) which was prepared in the suspension solution within $1 \mathrm{~h}$ of use; the tubes were centrifuged for $1 \mathrm{~h}$ at $165,000 \mathrm{~g}$. For collection of the gradients, the bottom of the centrifuge tube was pierced slightly off centre to avoid perturbing the pellet (the piercing unit manufactured by Buchler Co., Fort Lee, N.J., was used), and the gradients were pumped at a constant rate through a rectangular flow-cell $(0.4 \mathrm{~cm}$ pathlength, Uvicord, LKB Instruments) while being continuously monitored at $254 \mathrm{~nm}$.

Treatment of polyribosomes with trypsin, chymotrypsin, or EDTA. Suspensions of the free polyribosomes were incubated with trypsin or chymotrypsin under conditions specified in the text or in the appropriate legend. The incubations were carried out at $0^{\circ} \mathrm{C}$. Proteolysis was arrested by the addition of a five-fold ( $w / v)$ excess of trypsin-LBI. Solutions of trypsin and chymotrypsin were freshly prepared before each experiment and were free of contaminating ribonuclease activity in the concentration ranges employed. Two different procedures were followed: (1) The incubation mixture was layered directly on a $15-40 \%(w / v)$ sucrose gradient for determination of the polyribosomal extinction and radioactivity profiles, or (2) the incubation mixture was sedimented at $269,000 \mathrm{~g}$ for 45 min to provide a 'trypsin supernatant' (TS) which had all of the released radioactivity and a 'trypsin pellet' (TP) which had the trypsin-resistant, ribosome-bound radioactivity. The TCA-insoluble radioactive materials of TS were precipitated by the addition of $2 \mathrm{ml}$ of ice-cold $10 \%(\mathrm{w} / \mathrm{v})$ TCA. After $20 \mathrm{~min}$ on ice, the suspensions were filtered through $0.45 \mu \mathrm{m}$ Millipore filters which were washed successively with three $2-\mathrm{ml}$ portions of $10 \%$ and $2-\mathrm{ml}$ portions of $5 \%(\mathrm{w} / \mathrm{v}) \mathrm{TCA}$, three $2-\mathrm{ml}$ portions of ethanol and $5 \mathrm{ml}$ of ether. The washed filters were dried under an infra-red lamp for transfer into scintillation vials. Heating in $5 \%(\mathrm{w} / \mathrm{v}) \mathrm{TCA}$ in the presence of $\left[{ }^{12} \mathrm{C}\right]$ leucine carrier, as recommended by ZOMZELY $e$ t al. (1968) proved to be unnecessary and was therefore omitted. Bovine serum albumin $(100 \mu \mathrm{g})$ was added to each gradient tube before precipitating its contents with $2 \mathrm{ml}$ of ice-cold $10 \%$ (w/v) TCA, and the insoluble radioactive material was processed on Millipore filters, as just described. The TCA-soluble radioactivity of fraction TS was counted separately after removal of the acid by repeated ether extraction. 
To suspensions of polyribosomes in $0.5 \mathrm{ml}$ of $20 \mathrm{~mm}$-tris $(\mathrm{pH} 7.2)$ containing $25 \mathrm{mM}-\mathrm{KCl}$ was added $0.5 \mathrm{ml}$ of a $0.134 \mathrm{M}$-solution of Na-EDTA (pH 7) and after $10 \mathrm{~min}$ on ice, the suspension was layered on $5 \mathrm{ml}$ of a $15-50 \%$ (w/v) sucrose gradient and was centrifuged for $15 \mathrm{~h}$ at $53,000 \mathrm{~g}$ in the Spinco SW-25.1 rotor, fitted with adaptors for tubes of $6.5 \mathrm{ml}$ capacity. The gradient was processed for determination of the $E_{254}$ and radioactivity profiles as already described.

Counting of radioactivity. The TCA-insoluble radioactivity was determined by counting the Millipore filters in $10 \mathrm{ml}$ of scintillation fluid, containing $4 \mathrm{~g}$ of PPO and $0.1 \mathrm{~g}$ of dimethyl POPOP per litre of toluene. The total and the TCA-soluble radioactivities were counted in $15 \mathrm{ml}$ of a mixture of xylene, dioxane and ethyl cellosolve $(1: 3: 1$ by vol.) containing $14 \mathrm{~g}$ of PPO, $1.7 \mathrm{~g}$ of dimethyl POPOP and $60 \mathrm{~g}$ of naphthalene per litre. In later experiments, radioactivity was counted after mixing $1 \mathrm{ml}$ of sample with $2 \mathrm{ml}$ of Biosolv-3 (Beckman Co., Fullerton, Calif.) to which $10 \mathrm{ml}$ of the toluene scintillation solvent were added. The counting efficiency ranged between 75 and 85 per cent. Quenching corrections were carried out by the channels-ratio method. A Unilux-II (Nuclear Chicago Co., Des Plaines, Ill.) liquid scintillation spectrometer was used.

Analytical Procedures. Protein was determined according to LowRY, Rosebrough, FARr and RANDALL (1951) with bovine serum albumin as standard. RNA was determined by the procedure of FLECK and BEGG (1965) in which the lipid extraction step is omitted; the omission of the lipid extraction step in the determination of RNA in brain tissue avoids losses of RNA into the organic phase (SRIPATI, RUET and KHouvine, 1967). A factor of 41.5 was used to convert the $E_{260}$ readings (taken in a final volume of $1.3 \mathrm{ml}$ ) to $\mu \mathrm{g}$ of RNA $/ \mathrm{ml}$. Yeast RNA was used as standard. For the determination of phospholipid phosphorus (BARTLETT, 1959), samples were extracted with three successive portions of 4 vol. of chloroform-methanol $(2: 1, \mathrm{v} / \mathrm{v})$. A factor of 25 was used to convert the $\mu \mathrm{g}$ of $\mathbf{P}$ to $\mu \mathrm{g}$ of phospholipid (Hallinan and Munro, 1965).

High voltage electrophoresis: Portions $(1-1.2 \mathrm{ml})$ of fraction TS were lyophylized, the dry residue was suspended in distilled water, and samples were streaked on prewetted Whatman No. 1 paper $(6 \times 57 \mathrm{~cm})$. Electrophoresis (Electrophorator, Model D, Gilson Medical Electronics, Middleton, Wis.) was at $4000 \mathrm{v}$ for $20 \mathrm{~min}$ in $0.06 \mathrm{M}-\mathrm{Na}$-oxalate buffer $(\mathrm{pH} \mathrm{1.9)}$. Strips $(1 \times 6 \mathrm{~cm})$ of the dry paper were counted in the toluene scintillation solvent already described.

Polyacrylamide disc gel electrophoresis. The technique described by REISFELD, LEWIS and WILLIAMS, (1962) was used with fraction TS prepared as above for high voltage electrophoresis. After the run (conducted at $\mathrm{pH} \mathrm{4.2)} \mathrm{the} \mathrm{gel} \mathrm{was} \mathrm{extruded} \mathrm{and} \mathrm{immersed} \mathrm{for} 30 \mathrm{sec}$ in a dry-ice-acetone mixture $\left(-60^{\circ} \mathrm{C}\right)$. The frozen cylinder was then divided into about $351-\mathrm{mm}$ thick sections by means of the 'lateral' slicer (Canalco Co., Rockville, Md.). Each section was placed in a scintillation vial containing $1 \mathrm{ml}$ of Biosolv-3, the capped vials were incubated at $55^{\circ} \mathrm{C}$ for $16 \mathrm{~h}$ and the radioactivity was counted in $10 \mathrm{ml}$ of toluene scintillation solvent. The counting efficiency was about 75 per cent. Recoveries of the radioactivity applied to the gel were in excess of 80 per cent.

Chromatography on Cu-Sephadex and TLC. Fraction TS was processed on columns of Cu-Sephadex and the tryptic peptides were separated from the amino acids by the procedure described by FAZAKERLEY and BEST (1965). The peptide effluent from the Cu-Sephadex column was lyophylized, the residue was suspended in $2.4 \mathrm{ml}$ of ice-cold $70 \%(\mathrm{w} / \mathrm{v})$ ethanol and the suspensions was centrifuged at $3000 \mathrm{rev} / \mathrm{min}$ for $10 \mathrm{~min}$. The clear supernatant fluid was quantitatively transferred to another tube and reduced to about $0.5 \mathrm{ml}$ under $\mathrm{N}_{2}$. Samples were then streaked on a TLC plate coated with silica gel $\mathbf{G}$ according to RuTsCHARD (1964). Development by the solvent [chloroform-methanol-34\% $(\mathrm{v} / \mathrm{v})$ ammonium hydroxide $(2: 2: 1$ by vol.)] was allowed to proceed for a distance of $16 \mathrm{~cm}$. The area between the line of application of the sample and the solvent front was divided transversely into $16 \times$ $1-\mathrm{cm}$ wide lanes which were individually scraped for transfer to scintillation vials. For counting, $0.5 \mathrm{ml}$ of water followed by $10 \mathrm{ml}$ of the toluene scintillation solvent containing $10 \%(\mathrm{v} / \mathrm{v})$ of Biosolv-3 were added.

Electron microscopy. Samples were fixed in ice-cold $1.5 \%(\mathrm{v} / \mathrm{v})$ glutaraldehyde in $0.1 \mathrm{M}$-phosphate buffer $\left(\mathrm{pH} \mathrm{7.4)}\right.$ and post-fixed for $2 \mathrm{~h}$ in a $2 \%(\mathrm{w} / \mathrm{v})$ solution of ice-cold $\mathrm{OsO}_{4}$ in $0 \cdot 1 \mathrm{M}$-phosphate buffer (pH 7.4) also containing $5 \%$ (w/v) sucrose. After a brief buffer wash, the samples were dehydrated at room temperature in a graded series of alcohols and washed thrice with pure propylene oxide, once with propylene oxide-Epon $812(1: 1, \mathrm{v} / \mathrm{v})$ and once with pure Epon 812 . Embedding was in Epon 812 of medium hardness in 'beem' capsules with successive $24 \mathrm{~h}$ polymerizations at $37^{\circ}$, $45^{\circ}$ and $60^{\circ} \mathrm{C}$. The ultra-thin sections were mounted on bare 400 -mesh copper grids and were stained with $5 \%(\mathrm{w} / \mathrm{v})$ uranyl acetate in $50 \%(\mathrm{v} / \mathrm{v})$ ethanol. They were counterstained for no longer than 15 min with lead citrate and examined in a JEOLCO, JEM 6-A electron microscope.

\section{RESULTS}

Characterization of the polyribosomes. The UV (extinction) spectrum of the free polyribosomes exhibited an $E_{260} / E_{280}$ ratio of $1 \cdot 84$, which was also the value of its 
$E_{\max } / E_{280}$ ratio; the $E_{\max } / E_{\min }$ ratio $\left(E_{260} / E_{235}\right)$ was 1.48 . ZomZELY et al. (1966) reported $E_{\max } / E_{\min }$ ratios of about 1.5 and $E_{260} / E_{280}$ ratios of about 1.7 for 'mixed' ribosomes isolated from the cerebral cortex of adult rats. YAMAGAMI, MASUI and KaWAKITA, (1963) and YAMAGAMI and MoRI (1970) determined values of 1.65 for the $E_{\mathrm{max}} / E_{\mathrm{mln}}$ ratio of ribosomes from guinea pig brain and 1.58 for polyribosomes from 6-day rat whole brain, whereas DATTA and GHOSH (1963) and MURTHY and RAPPOPORT (1965) reported $E_{\max } / E_{\min }$ ratios of 1.75 for ribosomes from goat and rat brain, respectively.

The RNA, protein and phospholipid contents of the free polyribosomes before and after treatment with deoxycholate are summarized in Table 1. The preparation contained $0.26 \mathrm{mg}$ of protein and $0.153 \mathrm{mg}$ of RNA perg wet wt. cortex and exhibited an RNA/protein ratio of 0.59 before and 0.58 after treatment with deoxycholate. Therefore, since the phospholipid content was negligible, the preparation could be considered devoid of contamination by the membranes of the endoplasmic reticulum (MURTY and Hallinan, 1969). A morphological corroboration of the biochemical purity of the polyribosomes is illustrated in Fig. 1.

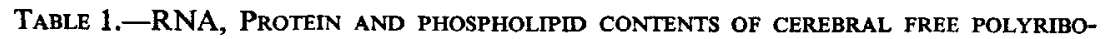
SOMES BEFORE AND AFTER TREATMENT WITH DEOXYCHOLATE

\begin{tabular}{lccccc}
\hline & $\begin{array}{c}\text { RNA } \\
(\mathrm{mg} / \mathrm{g})\end{array}$ & $\begin{array}{c}\text { Protein } \\
(\mathrm{mg} / \mathrm{g})\end{array}$ & $\begin{array}{c}\text { Phospholipid } \\
(\mathrm{mg} / \mathrm{g})\end{array}$ & $\begin{array}{l}\text { RNA } \\
\text { protein }\end{array}$ & $\begin{array}{l}\text { Phospholipid } \\
\text { protein }\end{array}$ \\
\hline Control & $\begin{array}{c}0.153 \pm 0.06 \\
(4)\end{array}$ & $\begin{array}{c}0.26 \pm 0.02 \\
(4)\end{array}$ & $\begin{array}{c}0.021 \pm 0.01 \\
(4)\end{array}$ & 0.59 & 0.08 \\
+DOC & $\begin{array}{c}0.111 \\
(2)\end{array}$ & $\begin{array}{c}0.16 \\
(2)\end{array}$ & $\begin{array}{c}0.013^{*} \\
(2)\end{array}$ & $0.58 \dagger$ & $0.08^{*}$ \\
$\begin{array}{l}\text { Percentage } \\
\text { recovery }\end{array}$ & 72.5 & 61.5 & & & \\
\hline
\end{tabular}

\footnotetext{
Means \pm S.D. or averages are given for the number of determinations given in brackets. All data are expressed per $\mathrm{g}$ wet wt. of cerebral cortex. Consult text for details.

* At the limit of reliability of the method; $\uparrow$ After correction for unequal recoveries of RNA and protein.

Abbreviation: DOC, deoxycholate.
}

The effects of trypsin and of EDTA. Trypsin caused a significant disaggregation of the polyribosomes (Fig. 2) if allowed to incubate for one minute and if its concentration exceeded $5 \mu \mathrm{g} / \mathrm{ml}$. Disaggregation could be avoided by shortening the incubation to 15 seconds and lowering the concentration of the protease to $0.5 \mu \mathrm{g} / \mathrm{ml}$ or less (Fig. 3). Increasing the concentration of trypsin to $5 \mu \mathrm{g} / \mathrm{ml}$ (Fig. 3C) resulted in visible disaggregation to monomers and dimers and also in the release of about half of the nascent radioactivity formed on the polyribosomes in vivo following a 5 minute pulse of $\left[{ }^{14} \mathrm{C}\right]$ leucine (Table 2; experiment 1). The trypsin-resistant radioactivity shifted toward the lighter regions of the gradient (Fig. 3C; tubes 5 to 10), i.e. in the direction of increased disaggregation. Moreover, like the polyribosomal disaggregation, the release of the nascent radioactivity (Table 2) could also be effectively modulated by prolonging incubation and/or by increasing the concentration of trypsin; yet it was not possible, under any of the conditions used, including the most rigorous ones (Table 2; experiment 3 ), to strip the polyribosomes of all their radioactivity. Thus, fraction TP always had radioactivity associated with it. 


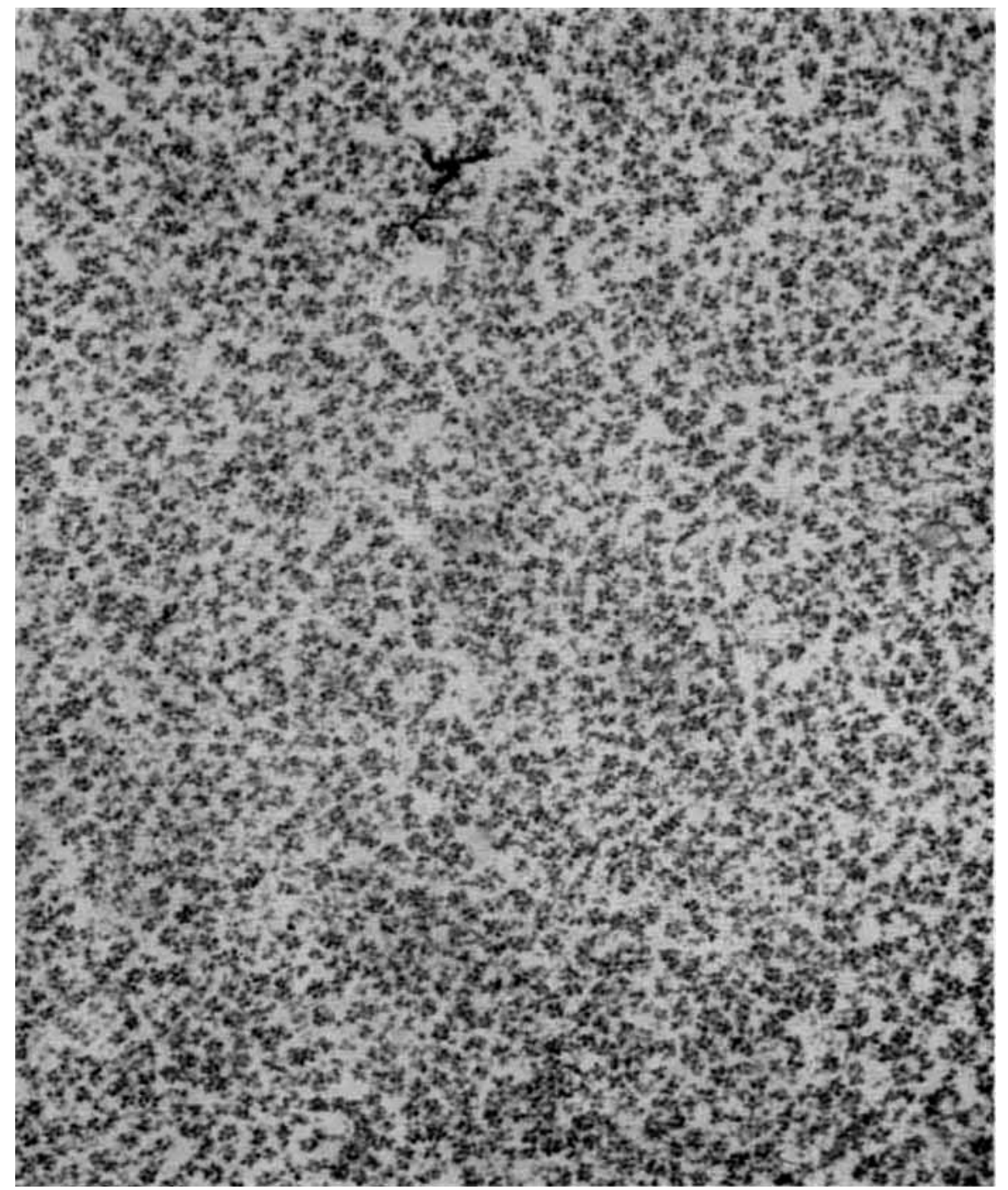

FIG. 1.-The appearance of the free polyribosomes in the electron microscope. The electron micrograph shows a representative field of free polyribosomes at a magnification of $\times 10,300$ (negative) and $\times 46,000$ (print). For preparative details, see 'Methods.' 


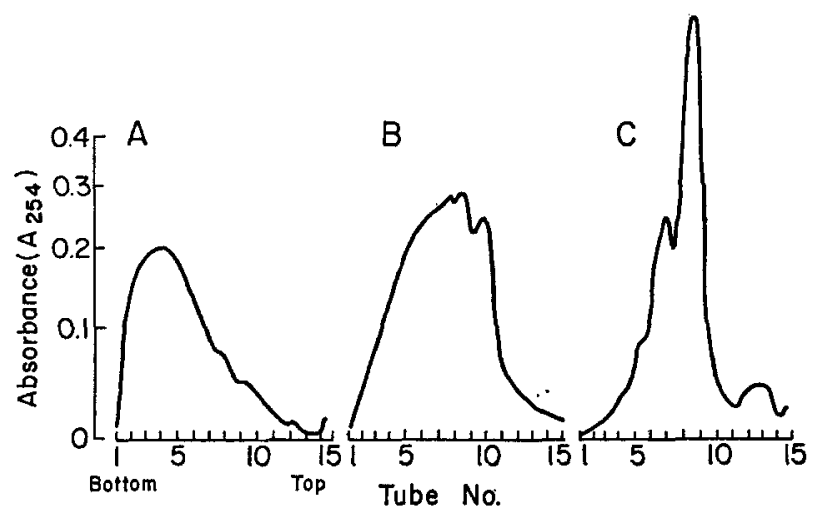

Fig. 2.-The effect of trypsin on polyribosomal aggregation. To triplicate $1 \mathrm{ml}$ portions of a polyribosomal suspension (about $0.25 \mathrm{mg}$ of protein $/ \mathrm{ml}$ ) were added: (A) $20 \mu \mathrm{g}$ of trypsin and $100 \mu \mathrm{g}$ of trypsin-LBI; (B) $5 \mu \mathrm{g}$ of trypsin alone and (C) $20 \mu \mathrm{g}$ of trypsin alone. Incubation $\left(0^{\circ} \mathrm{C} ; 1 \mathrm{~min}\right)$ was terminated by the addition of $100 \mu \mathrm{g}$ of trypsin-LBI to samples (B) and (C). The suspensions were then loaded on $15-40 \%(\mathrm{w} / \mathrm{v})$ sucrose density gradients (see Methods) and the gradient tubes were centrifuged at $165,000 \mathrm{~g}$ for $1 \mathrm{~h}$. The extinction profiles of the polyribosomal aggregates were monitored continuously as described in 'Methods'.

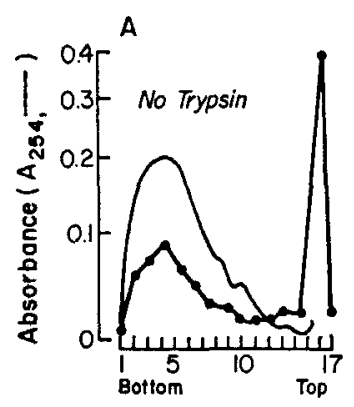

B

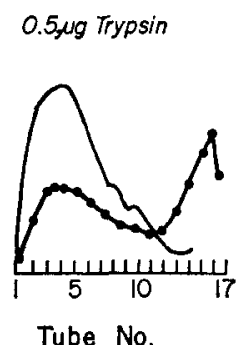

C

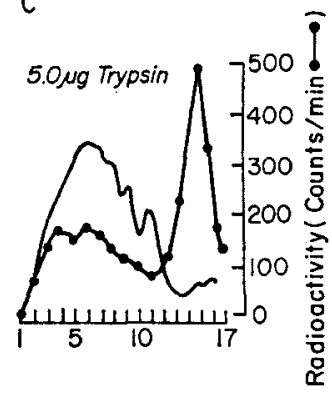

FIG. 3.-The absorbance and radioactivity profiles of cerebral polyribosomes after a 5 -min in vivo pulse of $\left[{ }^{14} \mathrm{C}\right]$ leucine. Free polyribosomes were isolated from cortices of animals which had received an injection of $\left[{ }^{14} \mathrm{C}\right]$ leucine (see 'Methods') $5 \mathrm{~min}$ before death. Three animals were used. The suspension of polyribosomes was divided into three portions of $0.8 \mathrm{ml}$ each $(0.2 \mathrm{mg}$ of protein). One served as control, and trypsin was added to the remaining two to achieve the concentration $/ \mathrm{ml}$ indicated. Incubation was for $15 \mathrm{~s}$ at $0^{\circ} \mathrm{C}$. It was arrested by the addition of a five-fold excess (by weight) of trypsinLBI and the ice-cold suspensions were loaded on $15-40 \%(\mathrm{w} / \mathrm{v})$ sucrose density gradients. The tubes were centrifuged at $165,000 \mathrm{~g}$ for $1 \mathrm{~h}$. The extinction profiles (left ordinate) were obtained by continuously monitoring the effluent at $E_{254}$, as described in 'Methods'. Radioactivity (right ordinate) was determined in each tube (also as described in 'Methods') and is expressed as c.p.m./tube.

Although treatment of the fraction TP with EDTA proved effective in releasing most of the radioactivity ( $>95$ per cent) which resisted trypsin, closer inspection of the $E_{254}$ profile of such an EDTA-treated preparation revealed perceptible radioactivity in the region of the gradient in which ribosomal subunits are known to sediment. Since these findings suggested that de novo assembly of ribosomes had taken place during the 5-minute $\left[{ }^{14} \mathrm{C}\right]$ leucine pulse which had been administered, the experiments were 
TABLE 2.-THE EFFECT OF CONCENTRATION OF TRYPSIN AND OF DURATION OF TRYPTIC DIGESTION ON THE RELEASE OF NASCENT RADIOACTIVITY

\begin{tabular}{|c|c|c|c|c|}
\hline \multirow[b]{2}{*}{$\begin{array}{c}\text { Experiment } \\
\text { No. }\end{array}$} & \multirow[b]{2}{*}{$\begin{array}{l}\text { Time of } \\
\text { incubation } \\
\text { (s) }\end{array}$} & \multirow[b]{2}{*}{$\begin{array}{l}\text { Trypsin } \\
(\mu \mathrm{g} / \mathrm{ml})\end{array}$} & \multicolumn{2}{|c|}{ Radioactivity } \\
\hline & & & $\begin{array}{l}\text { Released* } \\
\text { (Per cent) }\end{array}$ & $\begin{array}{l}\text { Resistant } f \\
\text { (Per cent) }\end{array}$ \\
\hline 1 & $\begin{array}{l}15 \\
15 \\
15 \\
15\end{array}$ & $\begin{array}{r}\text { none } \\
0.01 \\
0.05 \\
5.0\end{array}$ & $\begin{array}{r}0 \\
15 \\
24 \\
56\end{array}$ & $\begin{array}{r}100 \\
85 \\
76 \\
44\end{array}$ \\
\hline 2 & $\begin{array}{l}60 \\
60\end{array}$ & $\begin{array}{l}0.5 \\
5 \cdot 0\end{array}$ & $\begin{array}{l}68 \\
74\end{array}$ & $\begin{array}{l}32 \\
26\end{array}$ \\
\hline 3 & $30 \mathrm{~min}$ & $20 \cdot 0$ & 78 & 22 \\
\hline
\end{tabular}

Free polyribosomes were isolated from animals injected with $\left[{ }^{14} \mathrm{C}\right]$ leucine $5 \mathrm{~min}$ before death (see Methods for details). In expt. No. 1, the polyribosomes from three cortices (about $0.45 \mathrm{mg}$ of protein) were suspended in $3 \mathrm{ml}$ of $1 \mathrm{~mm}-\mathrm{Mg}$ acetate, $20 \mathrm{~mm}$-tris (pH 7.2), and $25 \mathrm{~mm}-\mathrm{KCl}$, and four samples of $0.70 \mathrm{ml}$ each were treated as indicated. The total radioactivity was determined on the remaining $0.2 \mathrm{ml}$. After $15 \mathrm{~s}$ of incubation with trypsin, a five-fold excess (by weight) of trypsin-LBI was added, as required, and the suspensions were centrifuged for $45 \mathrm{~min}$ at $269,000 \mathrm{~g}$. The total radioactivity of the supernatant, fraction TS, was determined. The trypsin-resistant radioactivity of fraction TP (the pellet) was obtained as the difference in radioactivity between fraction TS and the initial polyribosomal suspension. In expts. Nos. 2 and 3, the procedure was identical to that described above for expt. No. 1, except for the incubation conditions which varied as indicated.

* Total radioactivity of fraction TS. The radioactivity of the initial polyribosomal suspension was taken as 100 per cent.

$\dagger$ Calculated by difference. Resistant refers to fraction TP.

repeated with freshly isolated polyribosomes. As shown by the $E_{254}$ and the radioactivity profiles of such preparations after EDTA treatment (Fig. 4), both ribosomal subunits were labelled. In addition, as indicated by the relative displacement of the peak of radioactivity in the EDTA-treated preparation in comparison to the control preparation, EDTA presumably released peptidyl-RNA molecules (PHILIPPS, 1966) under conditions in which finished RNA-free polypeptides came off the control polyribosomes (Bretscher, Goodman, MENNINGER and SMITH, 1965).

\section{Modulation of the release and of proteolysis of the nascent polypeptides.}

(a) By the conditions in vitro. These experiments revealed (i) a rather uniform time course of release of the nascent polypeptides as determined by measuring the radioactivity of the TCA-insoluble portion at various intervals during the incubation with trypsin (Fig. 5A), and (ii) an equally uniform digestion of these polypeptides to TCA-soluble fragments (Fig. 5B). The effect of varying the concentration of trypsin on the TCA-soluble peptide fragments present at the end of $9 \mathrm{~min}$ of incubation is illustrated in Fig. 6.

(b) By the $\left[{ }^{14} \mathrm{C}\right]$ amino acid precursor. Prelabelled polyribosomes were incubated with trypsin and chymotrypsin, and the proportions of the released nascent polypeptides which were present in fraction TS as TCA-soluble fragments (TS, TCA-soluble, 

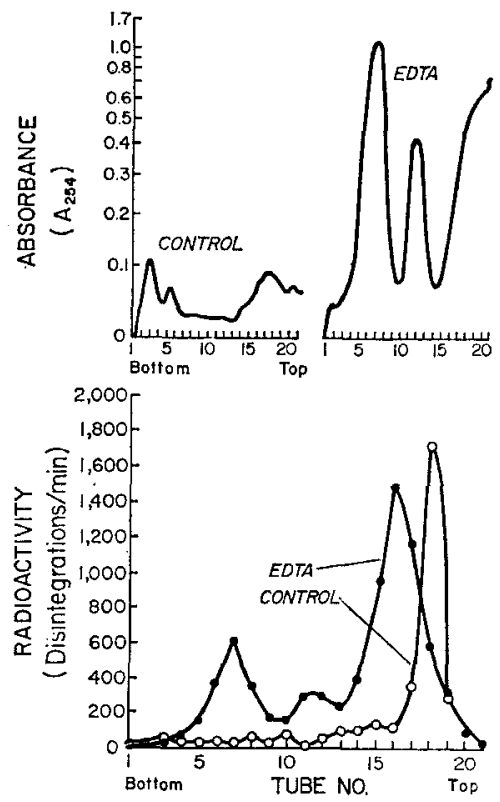

FIG. 4.-The effect of EDTA on cerebral free polyribosomes. Free polyribosomes were isolated from cortices of animals which had received an injection of $\left[{ }^{14} \mathrm{C}\right]$ leucine (see 'Methods') $5 \mathrm{~min}$ before death. Three animals were used. The suspension of polyribosomes was divided into two portions of $0.5 \mathrm{ml}$ (about $0.3 \mathrm{mg}$ of protein) and to one of these EDTA was added as described in 'Methods'. The other $0.5 \mathrm{ml}$ portion received an equal volume of saline. Both suspensions were centrifuged at $53,000 \mathrm{~g}$ for $15 \mathrm{~h}$ and the values for $E_{254}$ and radioactivity were determined as described in 'Methods'. The top half of the figure shows the extinction profiles of the control and the EDTA-treated preparation separately, whereas the bottom half illustrates the radioactivity profiles of the control and the EDTA-treated preparation together. Note the positional concordance of the large and small subunit $E_{254}$ and radioactivity peaks (tubes 7 and 12, respectively) in the EDTA-treated curves, and the virtual absence of radioactivity in the region of heavy aggregates (tubes 2 and 3 ) in the control curve.

Table 3) and as trypsin-resistant, TCA-insoluble radioactivity (TP, TCA-insoluble, Table 3) were compared as a function of the amino acid precursor. In these experiments it was assumed that a correlation might exist between the phenylalaninelabelled polypeptides and their susceptibility in vitro to chymotrypsin and, alternatively, between the arginine-labelled polypeptides and their susceptibility in vitro to trypsin. Leucine-labelled polypeptides were assumed to be equally susceptible to both proteases. The results (Table 3) conformed only partly to these expectations. Although the digestion of the arginine polypeptides by trypsin was no greater than that of the leucine polypeptides, the release of the arginine polypeptides from polyribosomes was more complete ( $3 \cdot 1$ vs. $7 \cdot 4$ per cent remaining in fraction TP). Similarly, although the digestion of the phenylalanine polypeptides by chymotrypsin was no greater than that of the leucine polypeptides, the release of the phenylalanine polypeptides from the polyribosomes was also more complete $(7 \cdot 2$ vs. $12 \cdot 3$ per cent in fraction TP). Moreover, as expected, the release of the arginine polypeptides by chymotrypsin was the least complete (19.7 per cent remaining in fraction TP).

(c) By the duration of the in vivo pulse. The susceptibility of the nascent polypeptides to release from the polyribosomes and, in turn, to proteolysis to smaller, TCA-soluble 

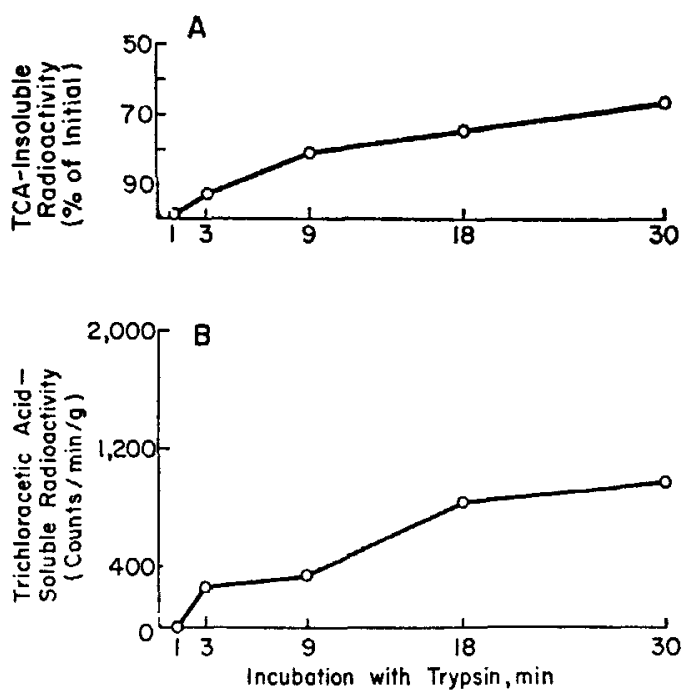

FIG. 5.-The effect of trypsin on the release of the nascent polyribosome-bound radioactivity. A. Polyribosomes were isolated from cortices of animals which had been injected with $\left[{ }^{14} \mathrm{C}\right.$ leucine $5 \mathrm{~min}$ before death (see Methods). Trypsin $(20 \mu \mathrm{g} / \mathrm{ml}$ ) was added to $2 \mathrm{ml}$ of a suspension of polyribosomes which was then incubated at $0^{\circ} \mathrm{C}$ for the intervals indicated. Samples $(300 \mu \mathrm{l})$ were withdrawn at intervals and their TCAinsoluble radioactivity was determined as described in Methods. The TCA-insoluble radioactivity of the initial polyribosomal suspension was taken as 100 per cent $(=5298$ c.p.m./g wet wt. of cortex).

B. At the intervals indicated, portions $(300 \mu)$ of the incubation mixture were withdrawn and the TCA-soluble radioactivity was determined by collecting the TCA used to precipitate the TCA-insoluble materials (in A) as it passed through the Millipore filters (see Methods). To obtain the values plotted, 483 c.p.m./g representing TCA-soluble background radioactivity (determined on the initial polyribosomal suspension) were subtracted at each interval. Note that after 9 min of incubation about 400 c.p.m./g were available as TCA-soluble radioactivity.

fragments, was examined as a function of the duration of the in vivo pulse $\left(\left[{ }^{14} \mathrm{C}\right]\right.$ leucine). To determine the susceptibility to release, $20 \mu \mathrm{g} / \mathrm{ml}$ of trypsin were added to suspensions of polyribosomes isolated from animals pulsed for 2,5 or $10 \mathrm{~min}$, and the release of the nascent chains was estimated at the end of the 30-min incubation at $0^{\circ} \mathrm{C}$ by determining the TCA-insoluble radioactivity which remained in fraction TP. Since the release was expressed (Fig. 7) as the percentage difference from the total TCA-insoluble radioactivity of the polyribosomal suspension (taken as 100 per cent; MALKIN and RICH, 1967), a larger fraction of the nascent radioactivity could be released from polyribosomes which had incorporated $\left[{ }^{14} \mathrm{C}\right]$ leucine for longer times. Of particular interest was the finding that 75 per cent of the radioactivity which became polyribosome-bound after 2 min of pulse was of sufficient chain length to be attacked by trypsin. The plot shown in Fig. 7 does not distinguish between the respective proportions of polypeptide available in fraction TS as TCA-soluble or TCA-insoluble materials. This distinction is made in Fig. 8 ; after 5 min of a $\left[{ }^{14} \mathrm{C}\right]$ leucine pulse, about 55 per cent of the tryptic and about 70 per cent of the chymotryptic digests of the polyribosomal suspensions were TCA-soluble; conversely, only a uniform 40 per cent was TCA-soluble after 2 min of pulse. 


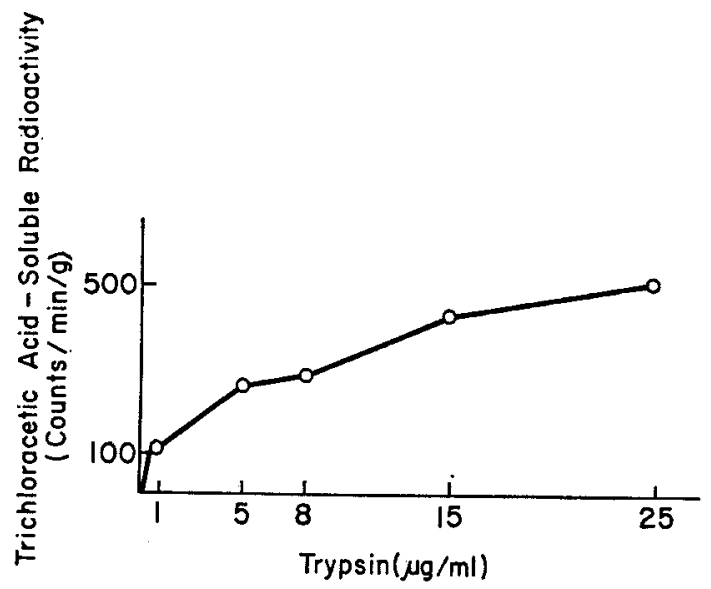

FIG. 6.-The effect of concentration of trypsin on the TCA-soluble radioactivity derived from the released polypeptides. Conditions for the preparation of labelled polyribosomes and for incubation with trypsin were as described in the legend of Fig. 5 , except that at the end of 9 min all samples were treated with TCA and the TCA-soluble radioactivity was determined (see Methods). Note that in this experiment, there were also about 400 c.p.m./g after incubation for $9 \mathrm{~min}$ with trypsin $(20 \mu \mathrm{g} / \mathrm{ml})$, in agreement with the similar value obtained in the experiment illustrated in Fig. 5B.

TABLE 3.-The Release AND THE PROTEOLYSIS OF THE NASCENT $\left[{ }^{14}\right.$ C]POLYPEPTIDES: THE EFFECT OF THE TYPE OF AMINO ACID PRECURSOR

\begin{tabular}{|c|c|c|c|c|c|}
\hline Protease & Fraction* & $\begin{array}{l}\text { Radioactivity } \\
\text { determined as: }\end{array}$ & $\begin{array}{c}\text { Leucine } \\
\text { (Per cent) }\end{array}$ & $\begin{array}{c}\text { Arginine } \\
\text { (Per cent) }\end{array}$ & $\begin{array}{l}\text { Phenylalanine } \\
\text { (Per cent) }\end{array}$ \\
\hline & TS & $\begin{array}{l}\text { TCA-soluble } \\
\text { TCA-insoluble } †\end{array}$ & $\begin{array}{l}54 \cdot 2 \\
45 \cdot 8\end{array}$ & $\begin{array}{l}33 \cdot 7 \\
66 \cdot 3\end{array}$ & - \\
\hline Trypsin & TP & TCA-insoluble + & $7 \cdot 5$ & $3 \cdot 1$ & - \\
\hline \multirow[t]{2}{*}{ Chymotrypsin } & TS & $\begin{array}{l}\text { TCA-soluble } \\
\text { TCA-insoluble } \dagger\end{array}$ & $\begin{array}{l}51 \cdot 2 \\
48 \cdot 8\end{array}$ & $\begin{array}{l}24 \cdot 8 \\
75 \cdot 2\end{array}$ & $\begin{array}{l}20 \cdot 6 \\
79 \cdot 4\end{array}$ \\
\hline & $\mathrm{TP}$ & TCA-insoluble + & $12 \cdot 3$ & $19 \cdot 7$ & $7 \cdot 2$ \\
\hline
\end{tabular}

* TS and TP are respectively the supernatant and the pellet resulting from the high-speed $(269,000 \mathrm{~g}, 45 \mathrm{~min})$ centrifugation of the protease-treated polyribosomal suspensions (see 'Methods').

$\dagger$ Calculated by difference; the total (TCA-insoluble + TCA-soluble) radioactivity of fraction TS being 100 per cent.

\$ The radioactivity of fraction TP refers to the TCA-insoluble radioactivity resistant to release by the protease and hence polyribosome-bound. It is expressed as a percentage of the sum of its own value + the total (TCA-insoluble + TCA-soluble) radioactivity of fraction TS.

Polyribosomes were isolated from cortices of animals injected $5 \mathrm{~min}$ before death with the radioactive amino acid indicated (see Methods for details). The polyribosomes were suspended in $1 \mathrm{~mm}-$

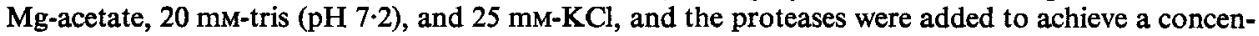
tration of $20 \mu \mathrm{g} / \mathrm{ml}$. After $30 \mathrm{~min}$ at $0^{\circ} \mathrm{C}$, protease action was arrested by the addition of the trypsinLBI, $100 \mu \mathrm{g} / \mathrm{ml}$ (see MALKIN and RICH, 1967, for the effectiveness of a trypsin inhibitor to arrest the action of chymotrypsin), and the suspensions were centrifuged for $45 \mathrm{~min}$ at $269,000 \mathrm{~g}$ to give fractions TS and TP respectively, the supernatant (TS) containing the totality of the released radioactivity and the pellet (TP) containing the trypsin-resistant, polyribosome-bound radioactivity. The total radioactivity of fraction TS was determined on a portion and the remainder of this fraction was treated with TCA, as detailed in Methods. The TCA-soluble portion of fraction TS was determined. The TCA-insoluble radioactivity was calculated as a percentage by subtracting the TCA-soluble radioactivity from the total radioactivity of fraction TS, taken as 100 per cent. The TCA-insoluble portion of fraction TP was also determined as indicated in Methods and values for it have been expressed as a percentage of the sum of its own radioactivity plus the total radioactivity of fraction TS. 


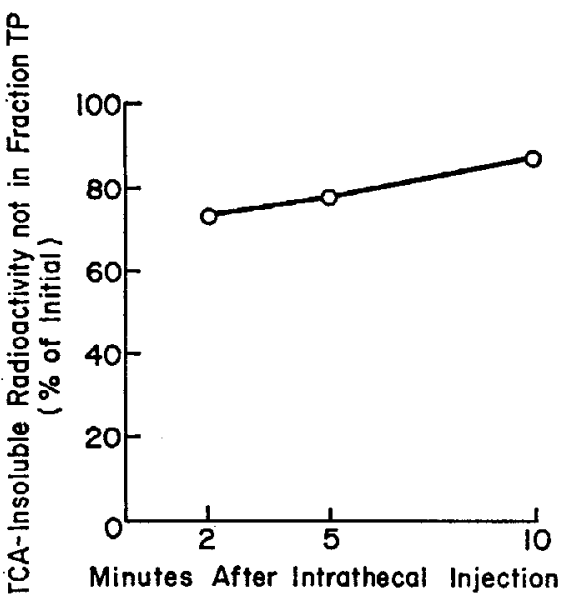

Fig. 7.--The effect of the duration of the in vivo pulse on the release of nascent polypeptides. Suspensions of polyribosomes isolated from animals which were pulsed with $\left[{ }^{14} \mathrm{C}\right]$ leucine, as indicated, were incubated with trypsin $(20 \mu \mathrm{g} / \mathrm{ml})$ for $30 \mathrm{~min}$. Three animals were used for each time point and each experiment was repeated at least twice. The total radioactivity of the initial polyribosomal suspensions and of fractions TP obtained from them by the procedure outlined in Methods was determined. Tryptic release is expressed as the percentage of the initial polyribosomal radioactivity which was no longer associated with fraction TP at the intervals examined (see Fig. 9 of MALKIN and RICH, 1967). The percentage values were $74 \cdot 1$ and 75.0 at $2 \mathrm{~min}, 82 \cdot 4,80 \cdot 2$ and 68.8 at $5 \mathrm{~min}$ and 80.0 and 87.4 at $10 \mathrm{~min}$.



FIG. 8.-The effect of the duration of the in vivo pulse on the appearance of TCAsoluble radioactivity in fraction TS. Suspensions of polyribosomes isolated from animals which were pulsed with $\left[{ }^{14} \mathrm{C}\right]$ leucine, as indicated, were incubated with $20 \mu \mathrm{g} / \mathrm{ml}$ of trypsin for $30 \mathrm{~min}$. Three animals were used for each time point and each experiment was repeated at least thrice. At the end of the incubation which was arrested by the addition of a five-fold excess (by weight) of trypsin-LBI, the suspensions were centrifuged at $269,000 \mathrm{~g}$ for $45 \mathrm{~min}$ to obtain fraction TS (see Methods) and the TCA-soluble radioactivity of this fraction was expressed as the percentage of the total radioactivity released. The actual per cent mean values \pm S.D. were: $41 \cdot 1 \pm 14.2$ at $2 \mathrm{~min}, 58.4 \pm 6.2$ at $5 \mathrm{~min}$ and $40 \cdot 8 \pm 15 \cdot 2$ at $10 \mathrm{~min}$. 


\section{Characterization of the nascent polypeptides}

(A) By high voltage electrophoresis. The electrophoretic profiles of the nascent polypeptides which became polyribosome-bound after 2,5 or $10 \mathrm{~min}$ of a $\left[{ }^{14} \mathrm{C}\right]$ leucine pulse were obtained by subjecting suitable suspensions of labelled polyribosomes to identical tryptic treatment $\left(20 \mu \mathrm{g} / \mathrm{ml}\right.$ for $30 \mathrm{~min}$ at $\left.0^{\circ} \mathrm{C}\right)$, followed by high voltage electrophoresis of the resulting fraction TS. The fastest moving cathodic component $(20-24 \mathrm{~cm}$ from the origin) which was readily discernible in the 2- and 5-min profiles,

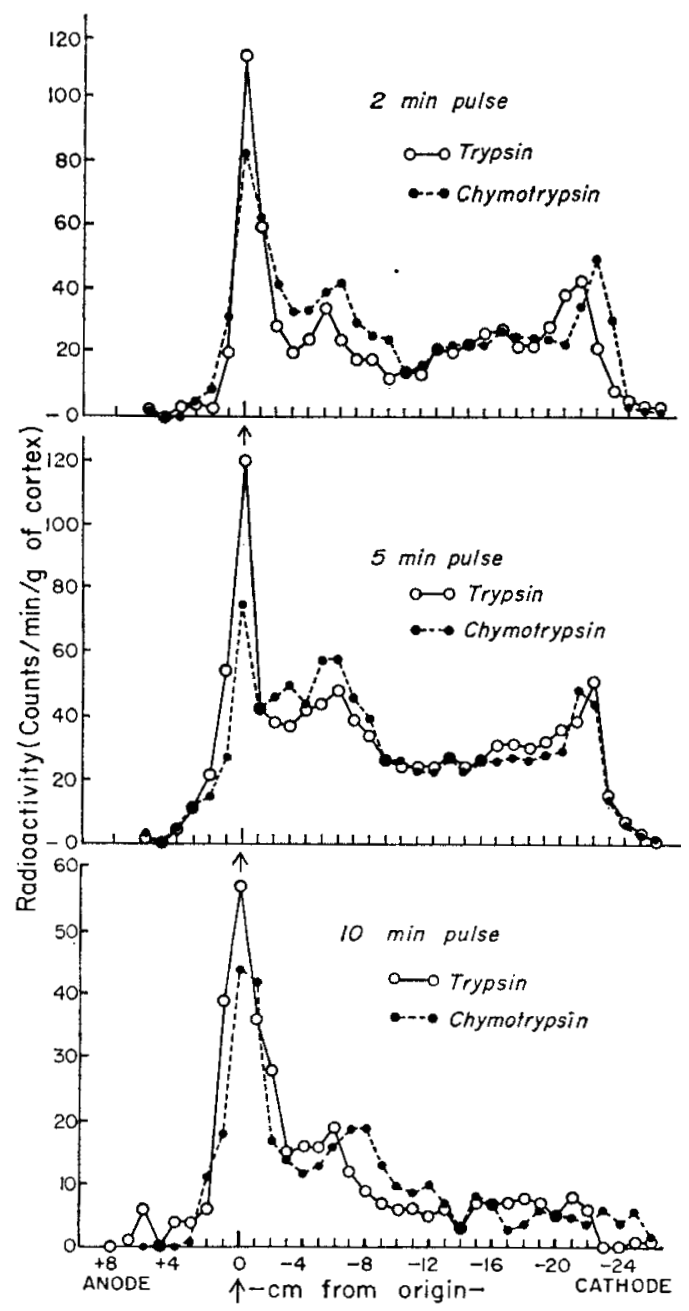

FIG, 9.-High voltage electrophoresis of the nascent polypeptides. Polyribosomes isolated from animals prelabelled with $\left[{ }^{14} \mathrm{C}\right]$ leucine were incubated with chymotrypsin or trypsin $(20 \mu \mathrm{g} / \mathrm{ml})$ for $30 \mathrm{~min}$ at $0^{\circ} \mathrm{C}$. The reaction was stopped by the addition of protease inhibitor $(100 \mu \mathrm{g} / \mathrm{ml})$. Portions of the supernatant fluids obtained by centrifugation of the incubated suspensions at $269,000 \mathrm{~g}$ for $45 \mathrm{~min}$ (fraction TS) were processed for high voltage electrophoresis as outlined in 'Methods'. The duration of the electrophoretic run was $20 \mathrm{~min}$. The profiles were determined by plotting radioactivity as a function of migration (in $\mathrm{cm}$ ) from the origin. 


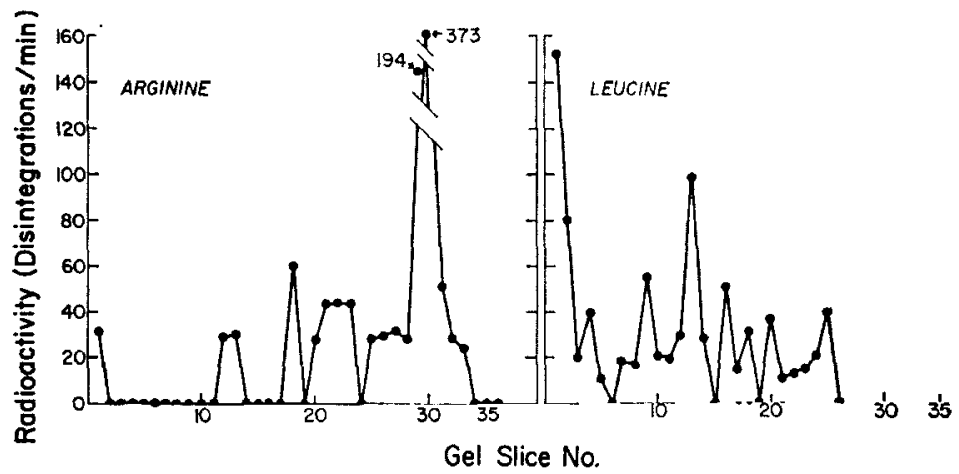

Fig. 10.-Polyacrylamide disc gel electrophoresis. Prelabelled polyribosomes ( $5 \mathrm{~min}$ of an in vivo pulse of $\left[{ }^{14} \mathrm{C}\right]$ amino acid) were incubated with trypsin $(20 \mu \mathrm{g} / \mathrm{ml})$ for 10 min at $0^{\circ} \mathrm{C}$ and fraction TS (see the legend of Figs. 8 and 9) was prepared and lyophylized. The dry residue was suspended in $0.2 \mathrm{ml}$ of distilled water, insoluble materials were removed by centrifugation ( $2000 \mathrm{rev} / \mathrm{min}$ for $10 \mathrm{~min}$ ) and electrophoresis was conducted in $15 \%$ (w/v) polyacrylamide gels for $60 \mathrm{~min}$ as described by REISFELD et al. (1962). For additional details, see Methods.

was no longer present in the fraction TS obtained after $10 \mathrm{~min}$ of pulse (Fig. 9). These findings indicated that nascent polypeptides did not remain bound to their polyribosomal template for more than a few minutes after their completion before being translocated to nonribosomal compartments of the cell.

(B) By polyacrylamide gel electrophoresis. Polyribosome-bound, nascent polypeptides available for tryptic or chymotryptic release into fraction TS at 5 min after a pulse with either $\left[{ }^{14} \mathrm{C}\right]$ arginine or $\left[{ }^{14} \mathrm{C}\right]$ leucine were analysed by the polyacrylamide disc gel procedure for basic proteins described by REISFELD et al. (1962). As expected

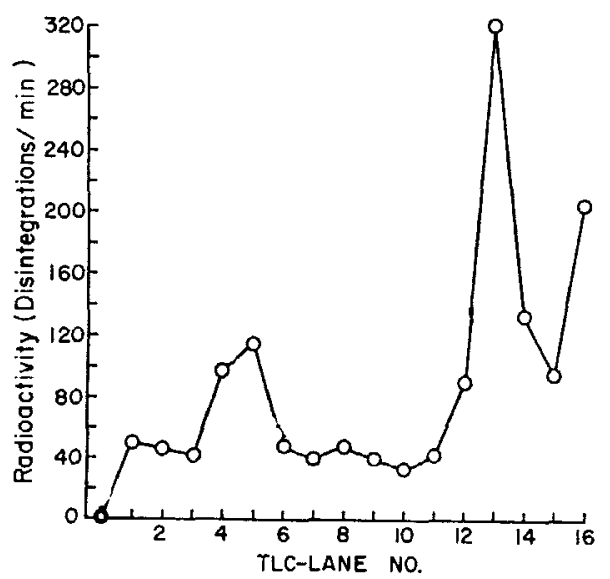

FIG. 11.-Thin-layer chromatography. Fraction TS was prepared as described in the legend of Fig. 8 and was lyophylized. The dry residue was suspended in $1 \mathrm{ml}$ of $0.05 \mathrm{M}$ borate $(\mathrm{pH} 11 \cdot 0)$ and was applied to the Cu-Sephadex (G-25) column $(2 \times 45 \mathrm{~cm})$. The remainder of the separation was as outlined by FAZAKERLEY and BEST (1965). The tubes containing the radioactive peptides were pooled and the radioactivity was extracted and subjected to monodimensional TLC, as described in Methods. The profile shown was determined by plotting the radioactivity as a function of the distance (in $\mathrm{cm}$ ) from the origin. The solvent front migrated a distance of $16 \mathrm{~cm}$. 
(Fig. 10), some of the arginine-labelled polypeptides migrated much faster than any of the leucine-labelled polypeptides and exhibited a large peak in the gel slice No. 29. On the other hand, the highest leucine-labelled peak and the smallest arginine-labelled peak were in gel slice No. 13. An additional difference between the two patterns was the much larger proportion of labelled peptides in the leucine profile which did not migrate away from the origin.

(C) By thin-layer chromatography. Fraction TS was obtained by treating a polyribosomal suspension (labelled in vivo with $\left[{ }^{14} \mathrm{C}\right]$ leucine for $5 \mathrm{~min}$ ) with trypsin $(20 \mu \mathrm{g} / \mathrm{ml}$ for $30 \mathrm{~min}$ at $0^{\circ} \mathrm{C}$ ). The mixture was lyophylized and the residue was suspended in $1 \mathrm{ml}$ of $0.05 \mathrm{M}$-borate ( $\mathrm{pH} \mathrm{11.0)}$ ). This suspension was applied to a column of $\mathrm{Cu}$ Sephadex, and the peptide fractions and the amino acid fractions were collected separately. No more than 10 per cent of the radioactivity applied to the $\mathrm{Cu}$-Sephadex column was eluted in the amino acid fraction, with about 90 per cent appearing in the peptide fraction. The latter fraction was examined by monodimensional TLC (Fig. 11) with indication of the presence of at least four distinct areas containing radioactive peptides.

\section{DISCUSSION}

CAMPAGNONI and MAHLER (1967), who developed the procedure for the isolation of free polyribosomes from the cortex of 17-21 day old rats, did not report analytical figures or yields in their original paper but in a later paper (MAHLER and BROWN, 1968) an average yield of $0.28 \mathrm{mg}$ of polyribosomal protein per $\mathrm{g}$ wet wt. cortex is mentioned, in excellent agreement with our value of $0.26 \mathrm{mg} / \mathrm{g}$ (Table 1). ZoMzeLY et al. (1966) reported a yield of $0.1 \mathrm{mg} / \mathrm{g}$ for RNA in 'ribosomal aggregates' obtained in the presence of deoxycholate from whole brains of 7-week old rats; no additional information on yield was provided in their later paper (ZOMZELY et al., 1968) in which brains of 23-25 day old rats were used. MURTHY (1966) has reported yields ranging from 0.18 to $1.02 \mathrm{mg}$ of protein per $\mathrm{g}$ depending on the procedure used to obtain ribosomes from whole brains of rats of unspecified age. Recently YAMAGAMI and MORI (1970) reported a protein yield of 0.56 and $0.45 \mathrm{mg} / \mathrm{g}$ of whole brain for a total tissue polyribosomal preparation obtained with the aid of $1 \%(\mathrm{w} / \mathrm{v})$ deoxycholate from 6and 90-day old rats, respectively.

After treatment of the free polyribosomes with deoxycholate (Table 1) to remove contaminating lipidic materials as recommended by MURTY and HaLlinan (1969) and a suitable correction for the differences in the recovery of protein and RNA (61.5 and 72.5 per cent, respectively), the RNA/protein ratio of our polyribosomal preparation remained unchanged. This finding, taken together with the excellent concordance of our protein data with those of MAHLER and BROWN (1968), indicates that our preparation contained no adsorbed membranes of the endoplasmic reticulum which, obviously, would contribute both protein and lipid. Contamination by extraneous proteins which do not contain lipid is considered highly unlikely in view of the 'clean' appearance of the preparation under the electron microscope.

CAMPAGNONI and MAHLER (1967) and later MAHLER and BROWN (1968) provided no solid analytical data on the RNA/protein ratios of free polyribosomal preparations of brain. Ribosomal RNA/protein ratios of about 1.0 were determined earlier by MURTHY (1966), who used the biuret and the orcinol reactions for protein and RNA, 
respectively. ZoMzely et al. (1966) reported some analytical data for their 'mixed' ribosomal preparation, but neither that paper nor their later one (1968) reports analytically determined ratios for free polyribosomes. They merely state (ZOMZELY et al., 1968): 'Incidentally, cerebral polyribosomes prepared in the absence of detergent exhibited the same high RNA to RNA + protein ratio (about 0.6) as the usual preparation' and do not specify whether they used spectral or analytical methods to support this statement. To obtain the RNA/protein ratio of 0.59 (Table 1), RNA was determined by a UV method (FLECK and BEGG, 1965) adapted for brain tissue in which the polyribosomes were not extracted with organic solvents (see 'Methods'). Moreover, unlike ZoMzely et al. (1966), we used the cerebral cortex of 12-13 day old rats and not the whole brain of 4- or 7-week old animals (ZoMzeLY et al., 1968). Recently, YAMAGAMI and MORI (1970) have shown that the RNA/protein ratio of polyribosomal preparations varies widely as a function of age of the animal, ranging from 1.06 for 6-day to 0.67 for 90 -day old brains; these authors also showed that at 12 days of postnatal age polyribosomes contain less than one-half of the RNA per gram of brain present in a similar preparation isolated from a 30 -day old rat brain. Our free polyribosomal preparation exhibited an $E_{260} / E_{280}$ ratio of $1 \cdot 84$, in excellent agreement with the ratio of 1.85 obtained by YAMAGAMI and MORI (1970) for polyribosomes of 6-day old rat brain and also with the ratio of 1.72 obtained by LERNER and JOHNSON (1970) for ribosomes of 11-day old mouse brain. The preparation also had an $E_{\max } / E_{\min }(260 / 235)$ ratio of 1.48 which, as ZOMZELY et al. (1966) have stated, is a sufficiently high value to indicate that the preparation is relatively free of extraneous proteins.

In the present experiments, the free polyribosomes were isolated from the cerebral cortex of 12-13 day old male rats in a medium containing no sucrose and in which the concentration of $\mathrm{Mg}^{2+}$ was $5 \mathrm{~mm}$. Previously, free polyribosomes of a comparable degree of structural integrity (i.e. containing almost no monomers or dimers; Fig. 2A) were demonstrated only by CAMPAGNONI and MAHLER (1967), who prepared the free polyribosomes from homogenates of the cerebral cortex of 18-24-day old rats in $0.35 \mathrm{M}$-sucrose and $10 \mathrm{mM}-\mathrm{Mg}^{2+}$. An additional difference between the present procedure and that of CAMPAGNONI and MAHLER (1967), again apparently not of crucial importance, was the layer of $0.5 \mathrm{M}$-sucrose (in $10 \mathrm{~mm}-\mathrm{Mg}^{2+}$ ) which we interposed between the sample containing the total tissue polyribosomes and the layer of $2 \cdot 0$ M-sucrose (also in $10 \mathrm{mM}-\mathrm{Mg}^{2+}$ ) through which the free polyribosomes are sedimented in the final step of both procedures. Our sucrose density gradients and those of Campagnoni and MaHLer (1967) had the same ionic composition, namely $1 \mathrm{mm-}$ $\mathrm{Mg}$-acetate and $25 \mathrm{mM}-\mathrm{KCl}$.

Thus, our results conform to the conclusions reached by CAMPAGNONI and MAHLER (1967), who stated that in order to isolate intact, heavily aggregated polyribosomes from immature cerebral cortex, it is not necessary to resort to the high concentrations of $\mathrm{Mg}^{2+}$ and $\mathrm{K}^{+}$prescribed (for quite different polyribosomal preparations) by ZomZely et al. (1966) and, more recently, by MACINNES, MCCONKEY and SCHLESINGER (1970).

Cerebral polyribosomes, prepared in the presence of an unusually high concentration of deoxycholate $(2 \%, w / v)$, reportedly suffer no damage when treated with trypsin, albeit under unspecified conditions (APPEL, DAvis and ScOTT, 1967). In the present study, our aim was to use trypsin and chymotrypsin as probes for the elucidation of the nature of the association of the growing nascent polypeptides with the ribosomal 
particles. Before establishing the conditions of proteolysis which would be required to do this with free polyribosomes from brain, and thus confirm the findings of MALKIN and RICH (1967) and of BLOBEL and SABATINI (1970), who worked with reticulocyte and hepatic polyribosomes respectively, we examined the relationship between the structural damage imparted to our preparation of free polyribosomes by trypsin and the release of nascent polypeptides from them. We found (Figs. 2 and 3) that treatment of the polyribosomes with trypsin resulted in a change of their state of aggregation only if the incubation conditions exceeded certain limits (Fig. 3; Table 2). Our studies thus revealed the apparent independence of the polyribosomal disaggregation elicited by trypsin from the release of nascent radioactivity equally well elicited by trypsin, since it was possible to cause (a) an appreciable release of the nascent radioactivity even while causing no structural damage to the polyribosomes, and conversely, (b) even when the polyribosomes were totally degraded, an incomplete release of the radioactivity.

The latter result is of particular significance because it confirms previous observations made with polyribosomes of other cells. In experiments on rabbit reticulocytes labelled in vitro as intact cells, MALKIN and RICH (1967) demonstrated that tryptic hydrolysis at low-temperature $\left(0^{\circ} \mathrm{C}\right)$ released only about one-half of the nascent polypeptides forming on the extensively labelled polyribosomes. More recently, BLOBEL and SABATINI (1970), working with free polyribosomes of rat liver labelled in vitro, were able to remove about 80 per cent of the radioactivity by incubating the polyribosomes with trypsin and chymotrypsin $(50 \mu \mathrm{g} / \mathrm{ml} \mathrm{each})$ for $5 \mathrm{~h}$ at $0^{\circ} \mathrm{C}$. Our results (Table 2) show that a maximum of about 80 per cent of the nascent radioactivity could also be removed from cerebral free polyribosomes labelled in vivo with a 5-min intrathecal pulse of $\left[{ }^{14} \mathrm{C}\right]$ leucine. The mild conditions necessary to release a maximal amount of the cerebral nascent polypeptides contrast with the rather drastic conditions required for the hepatic and the reticulocyte systems. The findings of trypsin-resistant ribosome-bound nascent radioactivity implies to us, as it did to MALKIN and RICH (1967) and to BLOBEL and SABATINI (1970), that the growing ends of the nascent polypeptides were protected against tryptic attack by ribosomal structure. Experiments in which fraction TP was treated with EDTA and 95 per cent of its radioactivity was released concomitantly with the dissociation of the ribosomes into subunits support this viewpoint and agree with the findings of MALKIN and RICH (1967). The finding that the chains released from the polyribosomes by EDTA were still attached to sRNA (Fig. 4, lower panel) is a further indication that, as in the reticulocyte, the attachment of the polypeptides to sRNA does not account for their resistance to trypsin. Plotting the percentage of the initial radioactivity of a prelabelled polyribosomal suspension which remained TCA-insoluble as a function of the time of incubation with trypsin (Fig. 5A) revealed that about 66 per cent was still TCA-insoluble at the end of $30 \mathrm{~min}$ of incubation. The c.p.m./g of TCA-soluble radioactivity generated during the same $30 \mathrm{~min}$ period is also plotted (Fig. 5B). No TCA-soluble radioactivity appeared in fraction TS during the first minute of incubation, a result which suggests, although by no means proves, that the digestion of the nascent polypeptides to TCAsoluble fragments can effectively proceed only after release from the polyribosomes as TCA-insoluble blocks has been achieved.

Although the results of the above experiments and of those shown in Table 3 clearly point to qualitative and quantitative differences in the susceptibility of the 
growing polypeptide chains to proteolytic attack, they reveal little concerning the regions of the nascent chains that are resistant to proteolysis. As pointed out by MALKIN and RICH (1967), 'the fact that the resistant portions are still attached to the ribosome suggests, but does not prove, that the more distal regions of the chains are being hydrolysed.' Similarly, BLOBEL and SABATINI (1970) have stated that: 'In a sufficiently long nascent polypeptide, two segments can be defined on the basis of their susceptibility to proteolysis. One segment is of variable length, is accessible to proteolytic enzymes, and is rapidly digested to acid-soluble peptides; the other is largely protected from digestion and accounts for the residual radioactivity ...'To gain information on whether an analogous situation holds for cerebral nascent polypeptides, advantage was taken of the fact that nascent polypeptide chains grow from the ribosome outward and thus selective labelling of the proximal region can be effected by pulsing the cortical cells with the $\left[{ }^{14} \mathrm{C}\right]$ amino acid for a length of time shorter than that needed for the complete synthesis of average-length chains. With only the proximal regions labelled, proteolysis should not release any radioactive material; with longer pulse times in vivo, the more distal regions of the chains will become labelled and trypsin should then release radioactive materials. Our results (Fig. 7) indicate that after barely 2 min of in vivo pulse about 75 per cent of the polyribosome-bound radioactivity was already susceptible to tryptic release and hence, most likely, consisted of full-length chains. Consequently, since $2 \mathrm{~min}$ appeared to be a considerably longer period of time than that required for the synthesis of complete chains, we could not ascertain unequivocally whether only the proximal ends of growing polypeptide chains were resistant to trypsin and hence were protected by ribosomal structure. However, the 10 per cent increase in the susceptibility of the chains (from 75 per cent at 2 min to about 85 per cent at $10 \mathrm{~min}$, Fig. 7) is compatible with this supposition. We did not carry out the elegant pulse-chase experiment designed by BLOBEL and Sabatini (1970), which permitted them to identify directly and unambiguously the resistant segment at the carboxy (ribosomal)-terminal end of the nascent polypeptide.

The chemical nature of the nascent radioactivity formed on the ribosomes of brain in vitro has been investigated by several workers. RUBIN and STENZEL (1965) studied the formation of a 'soluble protein unique to brain' and determined its isoelectric point and immunological reactivity, while CAMPBELl, MAHLER, MOORE and Tewari (1966) described a ribosomal system from immature brain capable of synthesizing a soluble, acidic protein. More recently, a polyribosomal system which converts about 40 per cent of the radioactivity added to the system to TCA-insoluble products was reported from the latter laboratory (MAHLER and Brown, 1968). To our knowledge, there have been no previous reports on the characterization of nascent polypeptides formed on brain polyribosomes in vivo. Unlike MALKIN and RICH (1967) and BLOBEL and SABATINI (1970), who focused on the characterization of the polyribosome-bound, trypsin-resistant segments of the growing polypeptides, we directed our efforts at the characterization of those segments of the growing chains which could be released from the polyribosomes by trypsin or chymotrypsin and which presumably reflected, therefore, the spectrum of molecules specifically assembled on the free polyribosomes. Although we have obtained preliminary results which suggest that the spectrum of nascent polypeptides formed on the free polyribosomes of cerebral cortex does not exactly match that formed on the endoplasmic reticulum-bound polyribosomes (Sellinger and OhlsSon, 1969; Sellinger, Ohlsson and Frankel, 1969), we cannot 
yet relate these findings to those of other workers who have clearly shown that different proteins are synthesized on the hepatic free and endoplasmic reticulum-bound polyribosomes (Peters, 1962; Hallinan, MURTY and Grant, 1968; REDMaN, 1969; Hicks, Drysdale and Munro, 1969; Ganoza and Williams, 1969; Sabatini and BLOBEL, 1970) and, moreover, that the structural proteins of the free and the endoplasmic-reticulum ribosomes are different (FrIDLENDER and WETTSTEIN, 1970).

Polypeptides released from polyribosomes prelabelled for $5 \mathrm{~min}$ are maximally susceptible to proteolytic digestion to TCA-soluble fragments (Fig. 8). However, upon examination of the entire fraction TS by high voltage electrophoresis (Fig. 9), no difference could be discerned between the 2- and the 5-min pulse profiles, both of which exhibit a rather distinct cathodic component. Since the $10-$ min pulse profile (Fig. 9, lowest panel) failed to reflect the presence of this cathodic component in fraction TS, we presume that its synthesis was completed within 2 min after administration of the precursor and that its residence in polyribosome-bound form did not last for more than $5 \mathrm{~min}$. Consequently, it was released from its polyribosomal template and translocated to non-ribosomal sites at sometime between 5 and $10 \mathrm{~min}$.

The diversity of the nascent polypeptides is illustrated (Fig. 10) by the disc gel profiles of the polypeptides released after $5 \mathrm{~min}$ of labelling with arginine and leucine. There is indication of the presence of materials which were selectively labelled by arginine, but into which leucine apparently failed to incorporate. Incidentally this experiment demonstrates the necessity of characterizing the nascent polypeptides with more than one labelled amino acid precursor.

Before specific synthetic functions can be assigned to the free polyribosomes as distinct from the endoplasmic reticulum-bound polyribosomes in any neuroanatomical area of the brain, the relative synthetic capacities of these polyribosomes in the two principal cell types comprising cerebral tissue, the neurons and the glial cells, must be determined. If, as ROSE (1969) has recently suggested, neurons and glial cells are independently programmed to manufacture their own cell-specific proteins, the fulfillment of the aforementioned requirement instantly becomes an item of the highest priority for study. Research on this aspect of cellular specificity in the nervous system is in progress in several laboratories, including our own (BLOMSTRAND and HAMberger, 1969; AzCurra, Lodin and Sellinger, 1969; Dutton and Barondes, 1969; Cicero, Cowan, Moore and Suntzeff, 1970; Sellinger and Azcurra, 1970; Johnson and Sellinger, 1970; Sellinger, AzCurRa, Johnson, OHlSSon and Lodin, 1971).

Acknowledgements-The expert technical assistance of Mrs JosePHINE C. SANTIAGo is gratefully acknowledged.

\section{REFERENCES}

ApPel S. H., Davis W. and ScotT S. (1967) Science, N.Y. 157, 836.

Azcurra J. M., Lodin Z. and Sellinger O. Z. (1969) Abstr. Commn., 2nd Meet. Internat. Soc. Neurochem. (Milan), p. 76.

Azcurra J. M. and Sellinger O. Z. (1967) Brain Res. 6, 359.

Bartlett P. (1959) J. biol. Chem. 234, 466.

Blobel G. and Sabatini D. D. (1970) J. Cell Biol. 45, 130.

Blomstrand C. and Hamberger A. (1969) J. Neurochem. 16, 1401.

Bretscher M. S., Goodman H. M., Menninger J. R. and SMith J. D. (1956) J. mol. Biol. $14,634$.

Campagnoni A. T. and Mahler H. R. (1967) Biochemistry, Easton 6, 959.

Campbell M. R., Mahler H. R., Moore W. J. and Tewari S. (1966) Biochemistry, Easton 5, 1174. 
Cicero T. J., Cowan W. M., Moore B. W. and Suntzeff V. (1970) Brain Res. 18, 25.

Datta R. K. (1966) Brain Res. 2, 301.

DatTA R. K. and Ghosh J. J. (1963) J. Neurochem. 10, 363.

DutTon G. and Barondes S. H. (1969) Science, N.Y. 166, 1637.

FAZAKERLEY S. and BEST D. R. (1965) Analyt. Biochem. 12, 290.

FLECK A. and BEGG D. (1965) Biochim. biophys. Acta 108, 333.

FrIDLENDER B. R. and WetTSTEIN F. O. (1970) Biochem. biophys. Res. Commun. 39, 247.

Ganoza M. C. and Williams C. A. (1969) Proc. natn. Acad. Sci., U.S.A. 63, 1370.

Hallinan T. and Munro H. (1965) Q. Jl. exp. Physiol. 50, 93.

Hallinan T., Murty C. N. and Grant J. H. (1968) Archs. Biochem. Biophys. 125, 715.

Hrcks S. J., Drysdale J. W. and Munro H. W. (1969) Science, N. Y., 164, 584.

Jacob M., Samec J., Stevenin J., Garel J. P. and Mandel P. (1967) J. Neurochem. 14, 169.

Johnson D. E. and Sellinger O. Z. (1970) J. Cell Biol. 47, 100a

LeRner M. P. and Johnson T. C. (1970) J. biol. Chem. 245, 1338.

Lowry, O. H., Rosebrough N. J., Farr A. L. and Randall R. J. (1951) J. biol. Chem. 193, 265.

MacInNes J. W., McConkey E. H. and SCHLESINGER K. (1970) J. Neurochem. 17, 457.

MAHIER H. R. and BROWN B. J. (1968) Archs. Biochem. Biophys. 125, 387.

MALKIN L. and RICH A. (1967) J. molec. Biol. 26, 329.

Mertrs I., Carn J. C., RozoK E. J. and Minard F. N. (1969) Experientia 25, 739.

MURTHY M. R. V. (1966) Biochim. biophys. Acta 119, 599.

MURPHY M. R. V. and RAPPOPORT D. A. (1965) Biochim. biophys. Acta 95, 132.

MurTy C. N. and Hallinan T. (1969) Biochem. J. 112, 269.

Nievel J. G. and Cumings J. N. (1967) Nature, Lond. 214, 1123.

Peters T. (1962) J. biol. Chem. 237, 1186.

Phillips G. R. (1966) J. mol. Biol. 15, 587.

RedMan C. M. (1969) J. biol. Chem. 244, 4308.

Reisfeld R. A., Lewis U. J. and Williams D. E. (1962) Nature, Lond. 195, 281.

Ritschard W. J. (1964) J. Chromat. 16, 327.

Rose S. P. R. (1969) In Applied Neurochemistry (Edited by Davison A. N. and Dobring J.) p. 332, F. A. Davis \& Co., Philadelphia.

RuBin A. L. and Stenzel K. H., (1965), Proc. natn. Acad. Sci., U.S.A. 53, 963.

Sabatini D. D. and Blobel G. (1970) J. Cell Biol. 45, 146.

Sellinger O.Z. and AzCuRra J. M. (1970) Trans. Am. Soc. Neurochem. 1, 22.

Sellinger O. Z., AZcurra J. M., Johnson D. E., OHLsson W. G. and Lodin Z. (1971) Nature, Lond. (In press.)

Sellinger O. Z., Azcurra J. M. and Ohlsson W. G. (1968) J. Pharmac. exp. Ther. 164, 212.

Seldinger O. Z. and Ohlsson W. G. (1969) Life Sci. 8, 1083.

Sellinger O. S., Ohlsson W. G. and Frankel A. J. (1969) Abstr. Commn., 2nd Meet. Internat. Soc.

Neurochem. (Milan), p. 359.

SRTPATI C. E., RuET A. and Khouvine Y. (1967) Experientia 23, 695.

Toschi G. (1959) Exptl. Cell Res. 16, 232.

Yamagami S., Masui M. and Kawakita Y. (1963) J. Neurochem. 10, 849.

YAMAGAMI S. and MORI K. (1970) J. Neurochem. 17, 721.

Zomzely C. E., Roberts S., Brown D. M. and Provost C. (1966) J. molec. Biol. $20,455$.

Zomzely C. E., Roberts S., Gruber C. P. and Brown D. M. (1968) J. biol. Chem. 243, 5396. 